\title{
Quantification of microbial communities in subsurface marine sediments of the Black Sea and off Namibia
}

\author{
Axel Schippers ${ }^{1,2}$, Dagmar Kock ${ }^{1,2}$, Carmen Höft ${ }^{1,2}$, Gerrit Köweker ${ }^{1,2}$ and Michael Siegert ${ }^{1,2}$ \\ ${ }^{1}$ Geomicrobiology, Federal Institute for Geosciences and Natural Resources, Hannover, Germany \\ 2 Faculty of Natural Sciences, Leibniz Universität Hannover, Hannover, Germany
}

\section{Edited by:}

Andreas Teske, University of North

Carolina at Chapel Hill, USA

\section{Reviewed by:}

Aharon Oren, The Hebrew University of Jerusalem, Israel

Timothy Ferdelman, Max Planck Institute for Marine Microbiology Germany

\section{${ }^{*}$ Correspondence:}

Axel Schippers, Bundesanstalt für Geowissenschaften und Rohstoffe, Stilleweg 2, 30655 Hannover, Germany.

e-mail: axel.schippers@bgr.de
Organic-rich subsurface marine sediments were taken by gravity coring up to a depth of $10 \mathrm{~m}$ below seafloor at six stations from the anoxic Black Sea and the Benguela upwelling system off Namibia during the research cruises Meteor 72-5 and 76-1, respectively. The quantitative microbial community composition at various sediment depths was analyzed using total cell counting, catalyzed reporter deposition - fluorescence in situ hybridization (CARD-FISH) and quantitative real-time PCR (Q-PCR). Total cell counts decreased with depths from $10^{9}$ to $10^{10}$ cells $/ \mathrm{mL}$ at the sediment surface to $10^{7}-10^{9}$ cells $/ \mathrm{mL}$ below one meter depth. Based on CARD-FISH and Q-PCR analyses overall similar proportions of Bacteria and Archaea were found. The down-core distribution of prokaryotic and eukaryotic small subunit ribosomal RNA genes (16S and $18 \mathrm{~S}$ rRNA) as well as functional genes involved in different biogeochemical processes was quantified using Q-PCR. Crenarchaeota and the bacterial candidate division JS-1 as well as the classes Anaerolineae and Caldilineae of the phylum Chloroflexi were highly abundant. Less abundant but detectable in most of the samples were Eukarya as well as the metal and sulfate-reducing Geobacteraceae (only in the Benguela upwelling influenced sediments). The functional genes $c b b L$, encoding for the large subunit of RuBisCO, the genes dsrA and aprA, indicative of sulfate-reducers as well as the mcrA gene of methanogens were detected in the Benguela upwelling and Black Sea sediments. Overall, the high organic carbon content of the sediments goes along with high cell counts and high gene copy numbers, as well as an equal abundance of Bacteria and Archaea.

Keywords: Benguela upwelling, Black Sea, CARD-FISH, deep biosphere, real-time PCR, sediments, subsurface

\section{INTRODUCTION}

The Black Sea and the Benguela upwelling system off the Atlantic coast of Namibia are both represent organic carbon-rich marine environments. Nevertheless, there are fundamental differences in the biogeochemistry and of these two settings. The Black Sea is the largest anoxic seawater basin on earth. It is characterized by high biological productivity in the oxygenated surface waters (Yilmaz et al., 2006). This and a deep anoxic water body below the chemocline at $100-150 \mathrm{~m}$ water depth (Neretin et al., 2007) provide suitable conditions for anaerobic microbial life and biogeochemical cycling in organic carbon-rich sediments. The sediments at water depths of $2000 \mathrm{~m}$ are under permanent anoxic and sulfidic conditions. Conversely, the Namibian continental margin underlies one of the most productive upwelling systems in the world. Periods of low oxygen, nitrate-rich, and sometimes sulfidic water, also leads to enhanced accumulation of organic carbon in the diatom-rich mud belt on the shelf. On the continental slope and rise the organic carbon flux to the underlying sediments is also relatively high. The sediments of these two marine areas have been well-studied for their biogeochemical processes (Niewöhner et al., 1998; Ferdelman et al., 1999; Brüchert et al., 2000, 2003, 2006; Fossing et al., 2000; Jørgensen et al., 2001, 2004; Emeis et al., 2004; Neretin et al., 2004; Knab et al., 2008; Dale et al., 2009; Goldhammer et al., 2010, 2011; Riedinger et al., 2010; Holmkvist et al., 2011) but microbiological data are available for surface sediments mainly (Schulz et al., 1999; Thamdrup et al., 2000; Schulz and Schulz, 2005; Coolen et al., 2006a; Neretin et al., 2007; Coolen and Shtereva, 2009; Schubotz et al., 2009; Julies et al., 2010). Only few microbiological data are published for subsurface sediments of the Black Sea and the Benguela upwelling system (Leloup et al., 2007; Schäfer et al., 2007; Blazejak and Schippers, 2010, 2011).

Subsurface marine sediments are populated by numerous prokaryotes mainly belonging to uncultivated phylogenetic lineages (Parkes et al., 2000; Teske, 2006; Biddle et al., 2008; Fry et al., 2008; Teske and Sørensen, 2008). The abundance of particular phylogenetic and physiological prokaryotic groups, i.e., Archaea and Bacteria, methanogens or sulfate-reducers, in subsurface sediments at various sites has been quantified based on 16S rRNA and functional gene analysis by quantitative, realtime PCR (Q-PCR), FISH, and catalyzed reporter depositionfluorescence in situ hybridization (CARD-FISH; Schippers et al., 2005, 2010; Biddle et al., 2006; Inagaki et al., 2006; Schippers and Neretin, 2006; Engelen et al., 2008; Nunoura et al., 2009; Webster et al., 2009; Breuker et al., 2011). While the detection of 16S rRNA genes may not be a good indicator for an active 
microbial community, FISH and CARD-FISH analyses, targeting intact ribosomal RNA, suggest that an active microbial community is present. Eukaryotic DNA comprising, e.g., fungi (Edgcomb et al., 2011) has been quantified in marine sediments at few sites in much lower concentration than prokaryotic DNA (Schippers and Neretin, 2006; Schippers et al., 2010). However, eukaryotic DNA may be preserved as fossil DNA from any buried biota and might be indicative for former biological communities (Coolen et al., 2006a,b; Inagaki and Nealson, 2006; Boere et al., 2011).

Sulfate-reducing microorganisms which are frequently found in near-surface sediments (Knoblauch et al., 1999; Sahm et al., 1999; Ravenschlag et al., 2000; Schippers et al., 2010), or methanogenic Archaea, were rarely detected in deep sediments (Parkes et al., 2005; Biddle et al., 2006; Inagaki et al., 2006; Teske, 2006; Teske and Sørensen, 2008; Webster et al., 2009). In addition to $16 \mathrm{~S}$ rRNA gene analyses, sulfate-reducers and methanogenic lineages of Archaea have been detected and quantified detecting their functional genes. Such genes encode for the dissimilatory sulfite reductase $(d s r A)$, adenosine $5^{\prime}$-phosphosulfate reductase subunit A (aprA), and methyl coenzyme $\mathrm{M}$ reductase ( $m c r A$, Parkes et al., 2005; Schippers and Neretin, 2006; Leloup et al., 2007; Wilms et al., 2007; Colwell et al., 2008; Engelen et al., 2008; Nunoura et al., 2009; Webster et al., 2009; Schippers et al., 2010; Blazejak and Schippers, 2011). The frequent occurrence of genes involved in sulfate reduction and methanogenesis indicates that microbial communities actively perform carbon and sulfur cycling under reduced redox conditions.

Despite heterotrophy seems to be dominant in subsurface sediments (D'Hondt et al., 2004; Biddle et al., 2006), autotrophy may play a role and has scarcely been investigated. There are different pathways of $\mathrm{CO}_{2}$ fixation, of which the Calvin-BensonBassham (CBB) cycle is the best described. The $c b b L$ gene encoding for the large subunit of the form I "red-like" enzyme ribulose1.5-bisphosphate carboxylase/oxygenase ( $\mathrm{RuBisCO}$ ) occurs in autotrophic Proteobacteria that fix $\mathrm{CO}_{2}$ via the $\mathrm{CBB}$ cycle (Selesi et al., 2007; Badger and Bek, 2008). This gene was so far only quantified in terrestrial (Breuker et al., 2011), but not in subsurface marine sediments.

In this study, the quantitative microbial community composition at six marine sediment stations from the Black Sea and in the Benguela upwelling area off Namibia at various sediment depths up to $10 \mathrm{~m}$ below seafloor (mbsf) was analyzed using total cell counting, CARD-FISH for the quantification of living Bacteria and Archaea, and 12 different Q-PCR assays for the quantification of particular phylogenetic or functional groups.

\section{MATERIALS AND METHODS SEDIMENT DESCRIPTION}

Samples were collected at six marine stations during two research vessel expeditions (Table 1). The M72-5 R/V Meteor cruise to the Black Sea took place in May/June 2007 (Figure 1). The sampled Black Sea sediments were permanently anoxic due to the overlaying anoxic water column. Sulfate reduction and methanogenesis are generally the predominant terminal biogeochemical processes for organic matter degradation (Jørgensen et al., 2004; Leloup et al., 2007). The sediments underlying the anoxic water column had an upper layer composed of laminated coccolith ooze with high organic carbon content, while an underlying sapropel is characterized by even higher organic content (Brumsack, 1989). At station 22 a sapropel layer occurred at a depth of 8 mbsf. This sapropel deposited $130 \mathrm{ka}$ ago after the Eem glacial.

The M76-1 R/V Meteor cruise to the Benguela upwelling area off Namibia took place in April/May 2008 (Figure 2). In the coastal upwelling area off Namibia, sediments were sampled along a transect course. This transect commenced at the deep subseafloor at the lower continental margin at $3795 \mathrm{~m}$ water depth (station 8 , GeoB 12808). This first core consisted of carbonate-rich deep sea clay, was oxic or suboxic with signs of bioturbation. The second station was situated at the upper continental margin at $1940 \mathrm{~m}$ water depth (station 3, GeoB 12803) was oxic and characterized by foraminifera and bioturbation. The third station was held at the shallow shelf in a mudbelt beneath a zone of high productivity (station 10, GeoB 12810) where foraminifera and dark olive colored mud characterized the sediment. A high abundance of Thioploca and Beggiatoa-like filaments from the surface down to $10-12 \mathrm{~cm}$ was found.

\section{SEDIMENT SAMPLING}

Sediment samples were taken from the near-surface sediment down to a depth of up to ca. $0.5 \mathrm{mbsf}$ employing a multicorer (MUC). Deeper sediments down to $10 \mathrm{mbsf}$ were sampled using a gravity corer (GC). The GC cores were quickly cut into $1 \mathrm{~m}$ sections onboard and immediately stored at $4^{\circ} \mathrm{C}$. For further section-wise processing within several hours, each $1 \mathrm{~m}$ section was subsequently split lengthwise into half-core sections. During sampling, the outer surface of the core was carefully removed to avoid contamination with seawater.

Table 1 | Sampled sediment stations and total organic carbon [TOC, data from S. Eckert and B. Schnetger (Black Sea), Y. Lin and K.-U. Hinrichs (Namibia)].

\begin{tabular}{|c|c|c|c|c|c|c|c|c|}
\hline Cruise & Area & Station & Sampling tool & Position & $\begin{array}{l}\text { Water } \\
\text { depth }(\mathrm{m})\end{array}$ & $\begin{array}{l}\text { Sampling depth } \\
\text { (mbsf) }\end{array}$ & $\begin{array}{l}\text { Number of } \\
\text { analyzed samples }\end{array}$ & TOC (\%) \\
\hline Black Sea & & 6 & MUC and GC & $43^{\circ} 25.91^{\prime} \mathrm{N} 32^{\circ} 16.48^{\prime} \mathrm{E}$ & 2027 & 8.8 & 19 & nd \\
\hline & & 22 & $\mathrm{GC}$ & $42^{\circ} 13.53^{\prime} \mathrm{N} 36^{\circ} 29.55^{\prime} \mathrm{E}$ & 840 & 9.7 & 19 & $0.3-4.4$ \\
\hline Benguela & Mudbelt & 10 & MUC and GC & $24^{\circ} 03.19^{\prime} \mathrm{S} 14^{\circ} 15.69^{\prime} \mathrm{E}$ & 120 & 3.4 & 16 & $4.1-13.4$ \\
\hline Upwelling & Upper slope & 3 & MUC and GC & $25^{\circ} 45.60^{\prime} \mathrm{S} 13^{\circ} 04.20^{\prime} \mathrm{E}$ & 1940 & 5.4 & 15 & $3.8-8.7$ \\
\hline
\end{tabular}




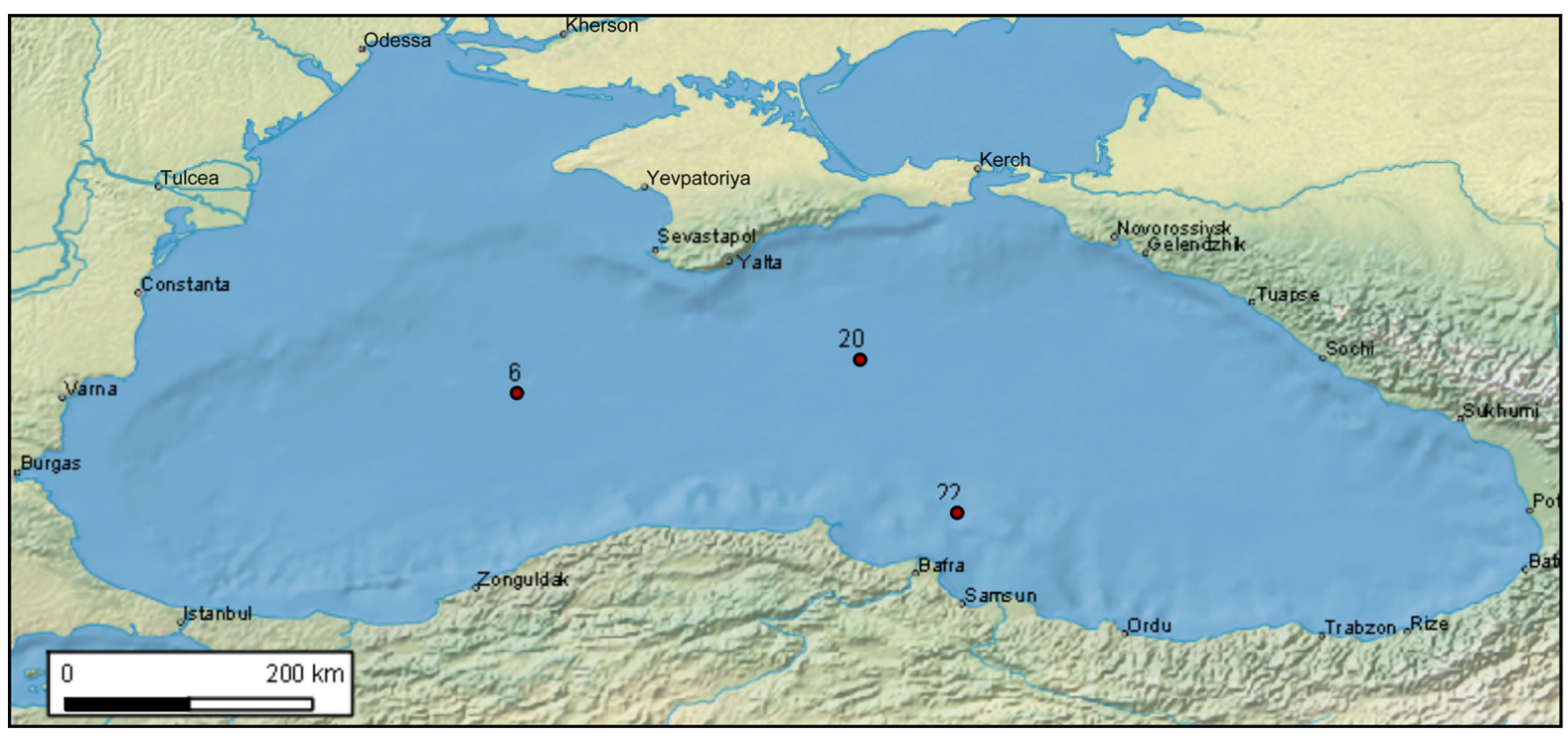

FIGURE 1 | Black Sea sediment stations of the cruise M72-5 analyzed in this study.

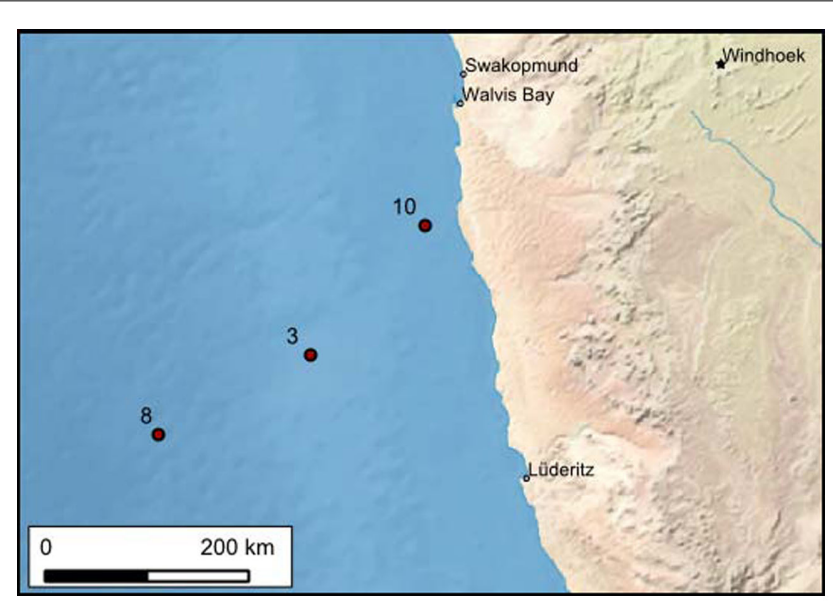

FIGURE 2 | Benguela upwelling transect sediment stations off Namibia of the cruise M76-1 analyzed in this study.

Microbiological samples for the quantification of microorganisms were taken with a sterilized $5 \mathrm{~mL}$ syringe of which the Leur head was cut off before. The uncontaminated center of the sediment core was sampled. For total cell counts, $0.5 \mathrm{~mL}$ sediment was fixed in $1 \mathrm{~mL}$ of a cold 4\% formaldehyde-PBS [phosphate buffered saline (ultra), $150 \mathrm{mM}$ sodium phosphate, $150 \mathrm{mM} \mathrm{NaCl}$, $\mathrm{pH} 7.2$ ] for $4-15 \mathrm{~h}$ at $4-10^{\circ} \mathrm{C}$, washed twice with cold PBS using a mini-centrifuge (Eppendorf) at $13000 \mathrm{rpm}$ for $10 \mathrm{~min}$ each, and finally stored at $-20^{\circ} \mathrm{C}$ in $1 \mathrm{~mL}$ PBS-ethanol $(1: 1)$ in $2 \mathrm{~mL}$ vials (Eppendorf), transported to BGR frozen with dry ice as air-freight, and stored in BGR at $-20^{\circ} \mathrm{C}$. For DNA extraction and quantification with Q-PCR, several grams of fresh sediment were frozen immediately after sampling at $-20^{\circ} \mathrm{C}$ in screw capped vials.

\section{TOTAL CELL COUNTS AND CARD-FISH}

Total cell numbers were determined in formaldehyde fixed samples by staining with SYBR Green ${ }^{\circledR}$ II following two different protocols. In analogy to acridine direct counts (AODC) we use the term SYBR Green $^{\circledR}$ direct counts (SGDC). While cells were counted in the sediment matrix as described by Weinbauer et al., 1998, SGDC1), cells were detached from sediment particles before counting using the protocol of Kallmeyer et al., 2008, SGDC2). CARD-FISH analysis was carried out as described previously (Pernthaler et al., 2002; Schippers et al., 2005) and filters were hybridized for Archaea and Bacteria using probes ARCH915 or EUB338 I-III as a mixture. As a negative hybridization control the probe NON338 was applied.

\section{QUANTITATIVE, REAL-TIME PCR ANALYSIS}

The quantitative composition of the total (active and inactive) microbial community was analyzed using Q-PCR of extracted DNA. High-molecular-weight DNA was extracted from $0.5 \mathrm{~g}$ of a frozen sediment sample employing a modified Fast DNA Spin Kit for Soil (Bio101) protocol (Webster et al., 2003). Sterilized quartz sand treated in a muffle furnace for organic carbon removal was used as negative control in the extraction procedure. Extracted DNA was amplified by Q-PCR using the device ABI Prism 7000 (Applied Biosystems) and different master mixes from the companies Applied Biosystems, Eurogentec or Invitrogen. Each DNA extract was measured in triplicate. After each Q-PCR, melting curves were measured for SYBR Green ${ }^{\circledR}$ I assays. The copy numbers of the 16S rRNA gene were quantified for prokaryotes, Archaea (Takai and Horikoshi, 2000), Bacteria (Nadkarni et al., 2002), Crenarchaeota (Ochsenreiter et al., 2003), the JS-1- and Chloroflexi-related bacteria (Blazejak and Schippers, 2010), and the metal and sulfate-reducing Geobacteraceae (Holmes et al., 2002). The 18S rRNA gene of Eukarya was determined as previously described (Schippers and Neretin, 2006). Functional genes were quantified as described elsewhere: $m c r A$ ( $m c r A$ assay 1, Wilms 
et al., 2007; mcrA assay 2, Steinberg and Regan, 2009), dsrA (Schippers and Neretin, 2006); aprA (Blazejak and Schippers, 2011), and $c b b L$ for (RuBisCO; Selesi et al., 2007).

\section{RESULTS}

Results of the quantitative microbial community composition in subsurface marine sediments of the Black Sea and the Benguela upwelling area off Namibia are shown in Figures $\mathbf{3}$ and 4, respectively.

\section{BLACK SEA}

\section{Total cell counts and CARD-FISH}

Total cells stained with SYBR Green ${ }^{\circledR}$ were counted following two different protocols. Depth profiles of total cell counts are shown in Figure 3 (left). For both protocols, the maximal cell counts were detected near the sediment surface at all three Black Sea stations. The total cell counts sharply declined within the first meter sediment depth, and slightly decreased further below. The method comparison showed that the highest cell counts for all depths were obtained using the protocol without detaching cells from sediment particles (SGDC1, Weinbauer et al., 1998). For this protocol, maximum cell counts declined from $10^{9}$ to $10^{10}$ cells $/ \mathrm{mL}$ at the sediment surface to $10^{7}-10^{8}$ cells $/ \mathrm{mL}$ below $1 \mathrm{mbsf}$. In comparison, the cell counts obtained from the cell detachment protocol (SGDC2, Kallmeyer et al., 2008) were about one order of magnitude lower within the first 1 mbsf but showed similar values than SGDC1 below one meter depth. An increase of cell counts could be observed at 8-9 mbsf at station 22 where the layer of the organic carbon rich sapropel was discovered.

Catalyzed reporter deposition - fluorescence in situ hybridization cell counts above the detection limit of $10^{5}$ cells $/ \mathrm{mL}$ were obtained from the sediment surface down to $2.5 \mathrm{mbsf}$ for the stations 6 and 20, and in the whole sampling depth of more than $8 \mathrm{mbsf}$ for station 22. Bacteria and Archaea occurred in overall equal numbers.

\section{Quantitative microbial community analysis by Q-PCR}

Q-PCR results for $16 \mathrm{~S}$ and $18 \mathrm{~S}$ rRNA and functional genes at the three Black Sea stations are shown in Figure 3 (middle and right, respectively). The Q-PCR data on archaeal and bacterial $16 \mathrm{~S}$ rRNA gene copy numbers matched well with the total cell counts (SGDC1). In overall agreement with the CARD-FISH data, Archaea were found in similar copy numbers compared with Bacteria at all three sites. At station 22 between 2 and $8 \mathrm{mbsf}$, Bacteria could not be detected although the bacterial candidate division JS-1 and the classes Anaerolineae and Caldilineae of the phylum Chloroflexi were detectable in this depth range. At the other depths at all three stations these specific bacterial groups occurred in similar gene copy numbers than the Bacteria (data for station 20 from Blazejak and Schippers, 2010). Likewise, the Crenarchaeota frequently occurred in high gene copy numbers compared with Archaea. In some samples, the copy numbers of Crenarchaeota were even higher than those of Archaea. Eukarya were only detectable down to 1 mbsf at stations 6 and 22. However, they were detected throughout the whole core of station 20 . Their 18S rRNA gene copy numbers were always lower than the prokaryotic $16 \mathrm{~S}$ rRNA gene copy numbers.
Similar depth profiles were obtained for the functional genes (Figure 3, right). However the investigated genes were not detectable between 1 and $7 \mathrm{mbsf}$ of station 22. Below, in the sapropel layer between 8 and $9 \mathrm{mbsf}$, they were again present. This was in good agreement with increased $16 \mathrm{~S}$ rRNA gene copy numbers and increased SGDC1. Genes encoding for enzymes of sulfate-reducers ( $d s r A$ and $a p r A$ ) were the most abundant (data for station 20 from Blazejak and Schippers, 2011). The $m c r A$ gene of methanogens was detected at the surface of all three stations and on the bottom of the stations 20 and 22 . The $c b b L$ gene was found only in the near-surface sediment and in two deeper layers of the station 20.

\section{BENGUELA UPWELLING AREA OFF NAMIBIA}

The quantitative distribution of the microorganisms at the three stations along the transect course of the Benguela upwelling area (Figure 4) was more heterogeneous than for the three Black Sea stations. At the Benguela upwelling sediment station 10 (Figure 4 bottom) a high abundance of Thioploca and Beggiatoa-like filaments was found at the near-surface sulfidic sediment of the shallow shelf. The other two stations on the continental slope at about $2000 \mathrm{~m}$ water depth (station 3, Figure 4 top) and at about $4000 \mathrm{~m}$ water depth (station 8 , Figure 4 middle) were oxic or suboxic and bioturbated. The transect course followed a trend of decreasing organic carbon content (TOC, Table 1). However the TOC values were always above $1 \%$, thus the sediments at all stations can be characterized as organic-rich and eutrophic.

\section{Total cell counts and CARD-FISH}

Depth profiles of total cell counts are shown in Figure 4 (left). For both, SGDC1 and SGDC2, the maximal cell counts were found near the sediment surface at all three Benguela upwelling stations. Like for the Black Sea stations, the total cell counts sharply declined within the first $1 \mathrm{mbsf}$, and slightly decreased further below at the stations 3 and 8 . At the station 10, no further decline of cell numbers was observed between 0.5 and $3.5 \mathrm{mbsf}$, the maximum sampling depth of this station. The maximum cell counts in the near-surface sediment were highest for the shelf station 10 with $10^{10}$ cells $/ \mathrm{mL}$ and between $10^{9}$ and $10^{10}$ cells $/ \mathrm{mL}$ for the two continental slope stations. While SGDC1 remained above $10^{9}$ cells $/ \mathrm{mL}$ at $3.5 \mathrm{mbsf}$ at station 10 , the numbers were about an order of magnitude lower at the same depth for the two slope stations. The method comparison shows that SGDC1 was always slightly higher than SGDC2 for all three stations at all depths.

Catalyzed reporter deposition - fluorescence in situ hybridization signals were observed at almost all stations and depths. However, Archaea were detectable in equal numbers compared with Bacteria only in the near-surface sediment. In the deeper layers only Bacteria (besides two samples with Archaea) were detected in significantly lower numbers than the corresponding SGDC1.

\section{Quantitative microbial community analysis by Q-PCR}

For the Benguela upwelling sediments, Q-PCR analyses of the $16 \mathrm{~S}$ and $18 \mathrm{~S}$ rRNA and the functional genes are depicted in Figure 4 (middle and right, respectively). The Q-PCR results for archaeal and bacterial 16S rRNA gene copy numbers were in good agreement with the total cell counts (SGDC1). In contrast to the CARDFISH data, Archaea were found in similar copy numbers compared with the Bacteria at all three stations (as for the Black Sea results). 
The archaeal copy numbers were higher than the bacterial ones in the deeper layers of station 10.
As found in the Black Sea sediments, the 16S rRNA gene copy numbers of the bacterial candidate division JS-1 and the classes
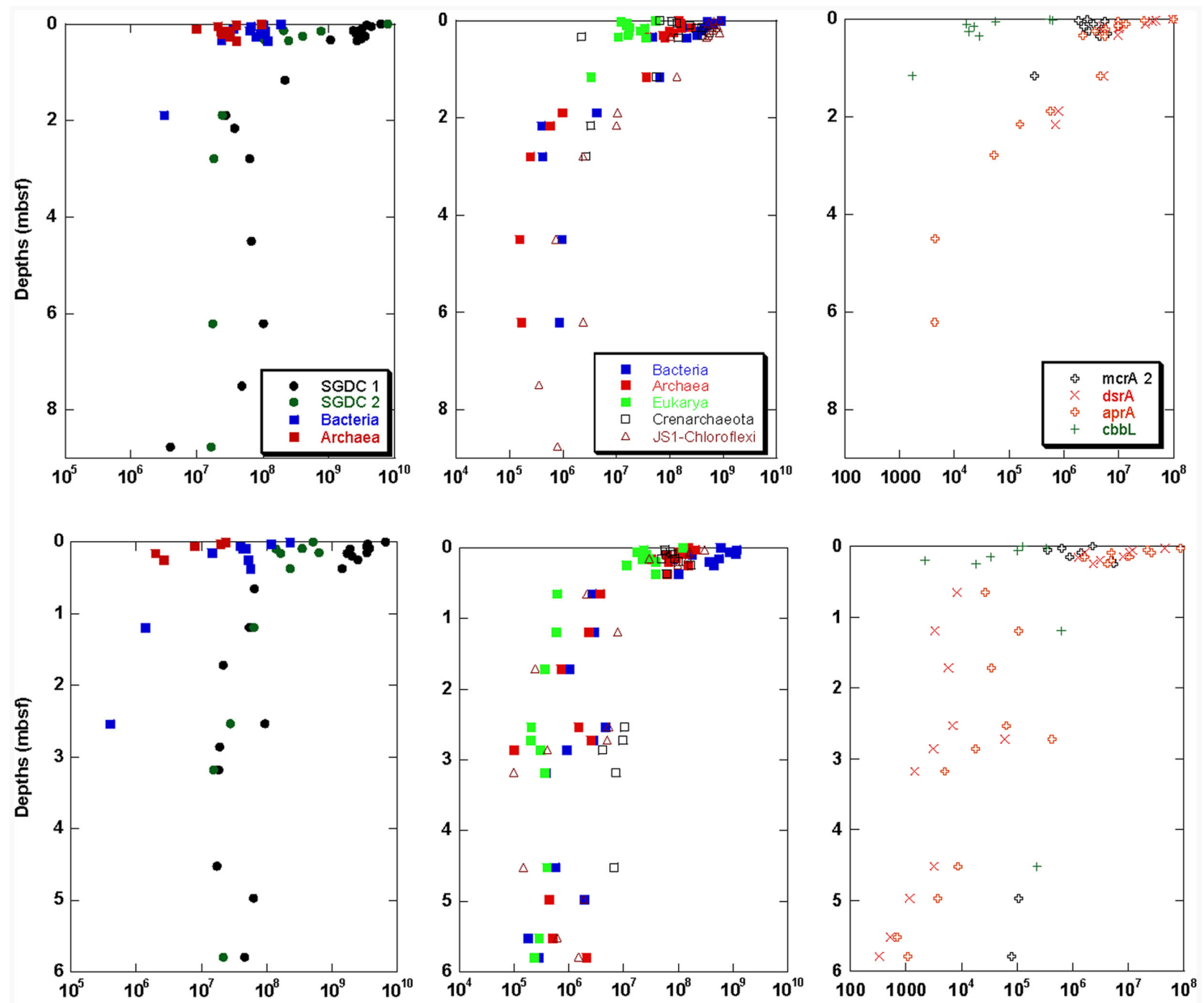

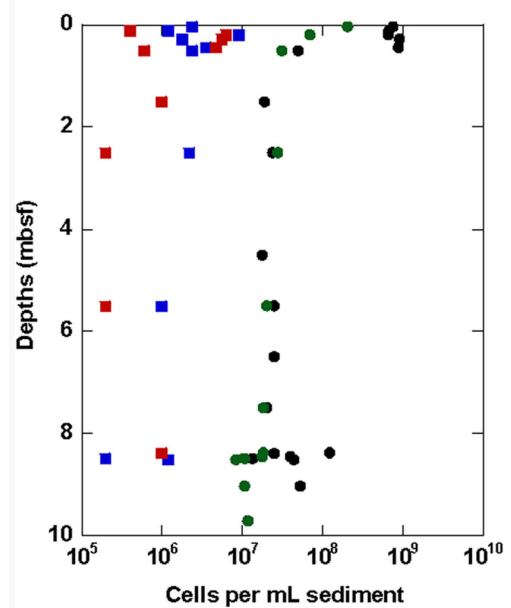

Total counts and CARD-FISH

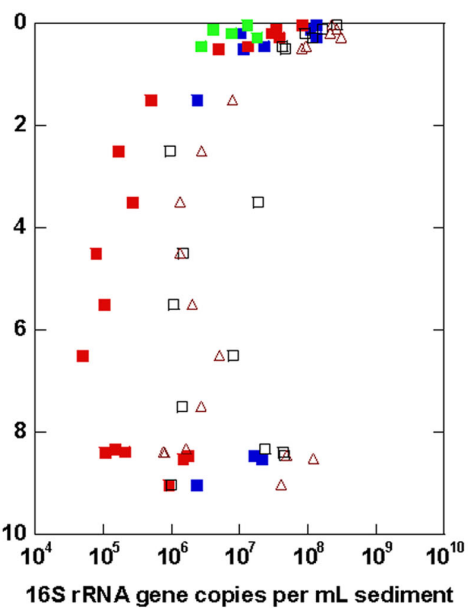

Q-PCR

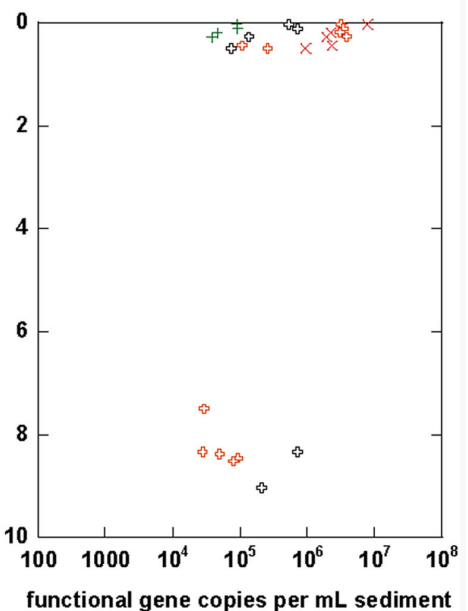

Q-PCR

FIGURE 3 | Black Sea sediment samples of stations $\mathbf{6}$ (top), 20 (middle), and 22 (bottom). Total cell counts obtained with two different methods (SGDC1 after Weinbauer et al., 1998, SGDC2 after Kallmeyer et al., 2008) and CARD-FISH numbers for Bacteria and Archaea (left), and Q-PCR quantification of 16S or 18S rRNA genes of Bacteria, Archaea, Eukarya, Crenarchaeota, and JS-1-Chloroflexi (middle) and the functional genes mcrA, dsrA, aprA, and cbbL (right). 

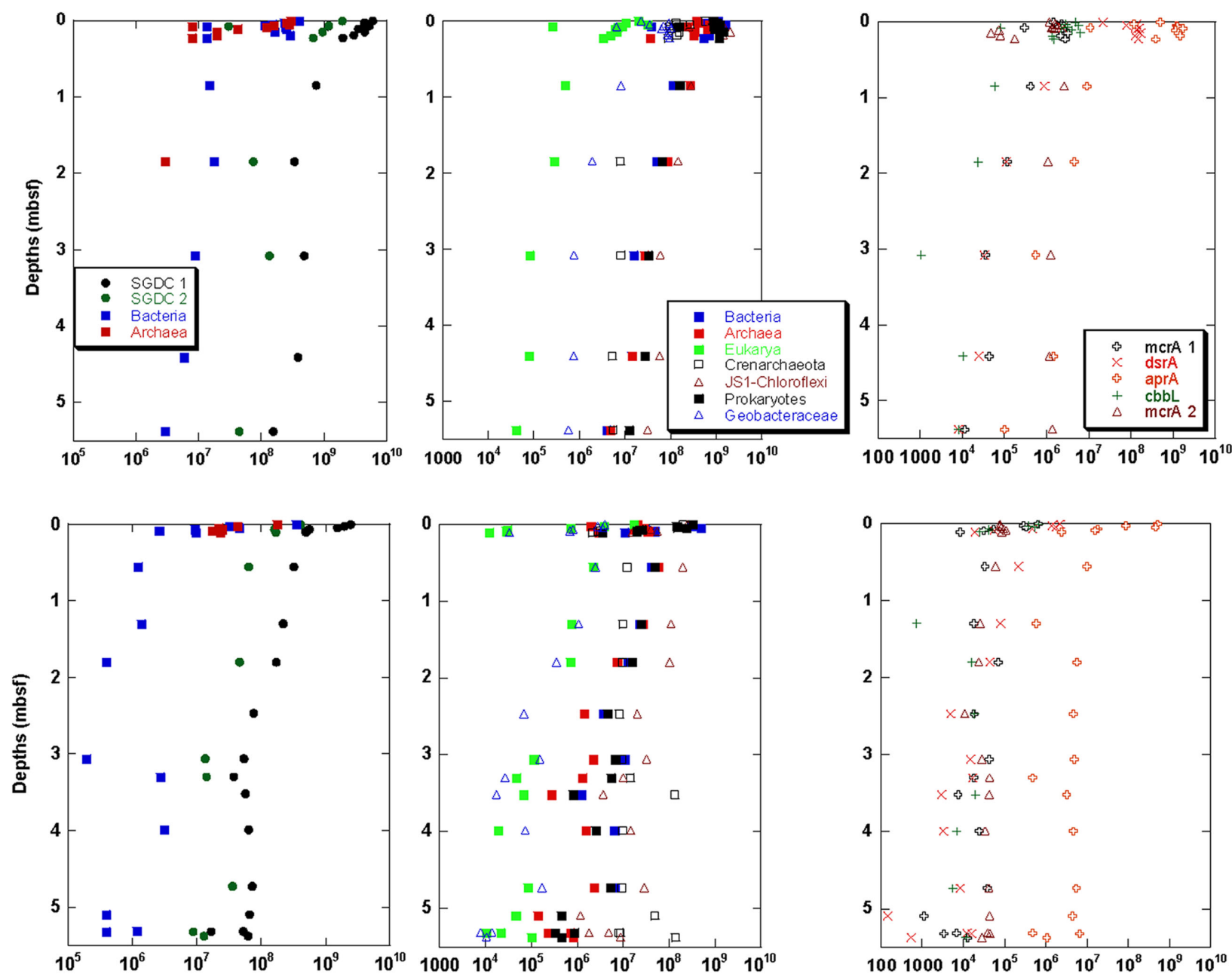

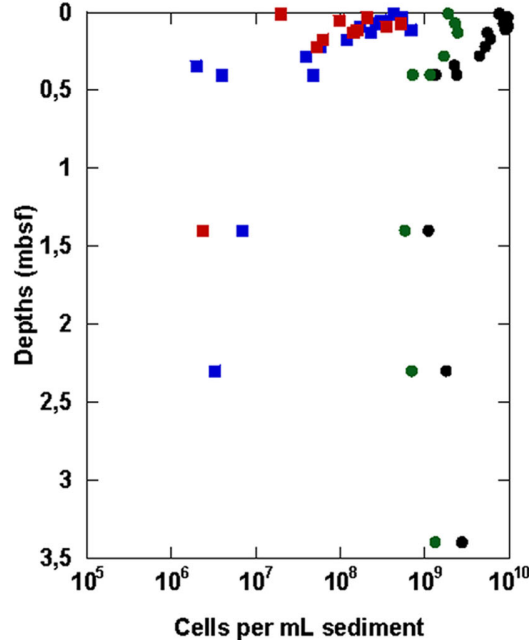

Total counts and CARD-FISH

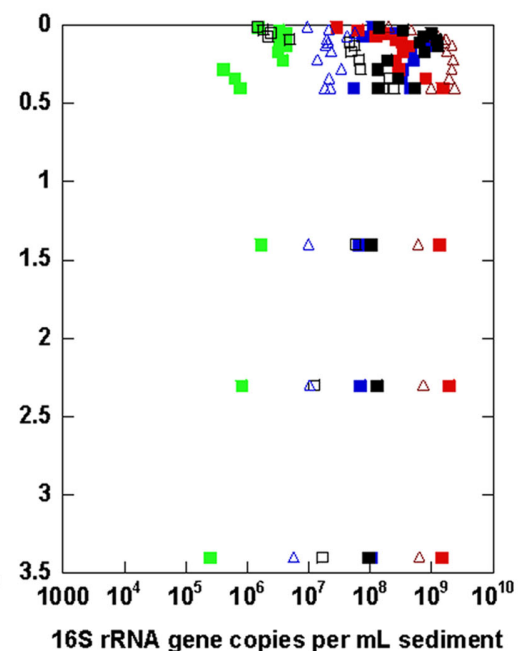

Q-PCR

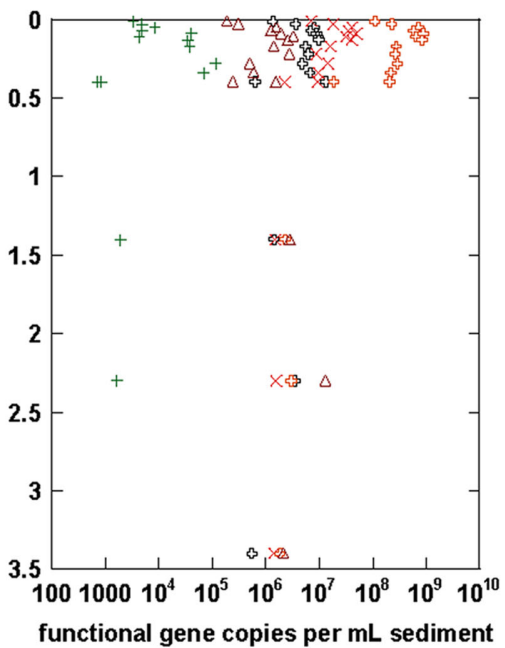

Q-PCR
FIGURE 4 | Benguela upwelling sediment samples of stations 3 (top), $\mathbf{8}$ (middle), and $\mathbf{1 0}$ (bottom). Total cell counts obtained with two different methods (SGDC1 after Weinbauer et al., 1998, SGDC2 after Kallmeyer et al., 2008) and CARD-FISH numbers for Bacteria and
Archaea (left), Q-PCR quantification of 16S rRNA genes of Prokaryotes, Bacteria, Archaea, Eukarya, Crenarchaeota, and JS-1-Chloroflexi (middle) and the functional genes mcrA 1 and 2, dsrA, aprA, and cbbL (right). 
Anaerolineae and Caldilineae of the phylum Chloroflexi as well as those of the Crenarchaeota occurred in similar numbers of $10^{6}$ to $10^{9}$ copies/mL than the $16 \mathrm{~S}$ rRNA gene copy numbers of Prokaryotes, Bacteria, and Archaea. The metal and sulfate-reducing family Geobacteraceae occurred at all three stations at all sediment depths in lower $16 \mathrm{~S}$ rRNA gene copy numbers. The least abundant phylogenetic group was the Eukarya which nevertheless occurred in all analyzed samples.

Similar depth profiles like for the phylogenetic groups (and SGDC1) were obtained for the functional genes. All functional genes were detected in almost all analyzed samples. Among the functional groups, sulfate-reducers were most abundant, especially their functional gene aprA occurred with maximum numbers of $10^{9}$ copies $/ \mathrm{mL}$ sediment. In contrast to the Black Sea sediments, both $m c r A$ assays 1 and 2 of methanogens provided successful gene amplification, and $m c r A$ and $c b b L$ occurred not only in the near-surface sediment but also in the deeper subsurface sediment.

\section{DISCUSSION}

Microbial communities in the subsurface marine sediments of the Black Sea and the Benguela upwelling area off Namibia have been analyzed. Total cell counts, CARD-FISH data as well as Q-PCR analysis exhibited a high abundance of prokaryotes in the eutrophic, organic carbon-rich sediments at all six stations. A similar high abundance of prokaryotes analyzed by the same methods has been detected in organic carbon-rich sediments of the Peru margin (ODP Leg 201, D'Hondt et al., 2004; Schippers et al., 2005; Inagaki et al., 2006), gas-hydrate bearing sediments from the Cascadia margin (ODP Leg 204; Inagaki et al., 2006), northeast Pacific ridge-flank sediments (IODP Exp. 301; Engelen et al., 2008), tidal flat sediments of the North Sea (Wilms et al., 2007), and sediments off Sumatra (Schippers et al., 2010). Less organic carbon-rich marine sediments exhibited, as expected, a lower abundance of prokaryotes as shown for the equatorial Pacific (ODP Leg 201; D'Hondt et al., 2004; Schippers et al., 2005), the Porcupine Seabight (IODP Exp. 307; Webster et al., 2009), and the Gulf of Mexico (IODP Exp. 308; Nunoura et al., 2009). Oligotrophic, organic carbon-poor marine sediments contain generally very low cell numbers as shown for the South Pacific Gyre (D'Hondt et al., 2009), and the Western flank of the Mid-Atlantic Ridge at $23^{\circ} \mathrm{N}$ (North Pond; A. Breuker and A. Schippers, unpublished). A compilation of mean cell numbers determined by total cell counting, Q-PCR, and CARD-FISH in subsurface marine sediments of various sites is given in Table 2 .

In this study, a decrease of cell numbers with sediment depth was observed for all stations as described for subsurface marine sediments (Parkes et al., 1994, 2000; D'Hondt et al., 2004). However, in the sapropel layer at $8-9$ mbsf of the Black Sea station 22 , the cell as well as the gene copy numbers again increased by more than an order of magnitude, explainable by the increased organic carbon content of the sapropel serving as substrate for the microorganisms. Such an increase in biomass at distinct geologically different sediment layers has been described for other sediments as well (Inagaki et al., 2003; Parkes et al., 2005), and in particular for sapropels (Coolen et al., 2002).

In the sediments of this study, total cell counts were determined after staining with SYBR Green ${ }^{\circledR}$ following two different protocols. Cell numbers directly counted in the sediment matrix (SGDC1) were verified by comparing the counts with those of the SGDC2 protocol in which the cells were detached from sediment particles before counting. The general depth trends of SGDC1 could be confirmed with SGDC2. However, the cell detachment method revealed somehow lower cell numbers as previously shown for subsurface marine sediments off Sumatra (Schippers et al., 2010) and terrestrial sediments in the Chesapeake area (Breuker et al., 2011). The difference in cell numbers between these two protocols was never higher than one order of magnitude in our study. A comparison of the total cell counts with the 16S rRNA gene copy numbers of the Bacteria and Archaea obtained by Q-PCR gives a good match for SGDC1 as well as for SGDC2, indicting a high reliability of the data for these quantification methods. CARD-FISH cell numbers were always considerably lower than SGDC 1. This indicates that either the majority of the cells was inactive, which seems to be unlikely in the organic-rich sediments, or more likely, insufficient cell wall permeabilization in the CARD-FISH protocol and mismatches of the archaeal CARD-FISH probe ARCH915 with predominant environmental gene sequences (Teske and Sørensen, 2008) prevented the detection of many living cells, especially Archaea.

The proportions of Bacteria and Archaea in marine sediments have shown to be highly variable in different sediments and sediment layers. Based on CARD-FISH and Q-PCR analyses overall similar proportions of Bacteria and Archaea have been determined for sediments studied here. An almost equal abundance of Bacteria and Archaea has also been found for the Porcupine Seabight (IODP Exp. 307; Webster et al., 2009), the northeast Pacific ridgeflank (IODP Exp. 301; Engelen et al., 2008), and Sumatra forearc basins (Schippers et al., 2010). By contrast, using Q-PCR it has been discovered that Bacteria dominated other sediments such as the Sea of Okhotsk (Inagaki et al., 2003), the Gulf of Mexico (IODP Exp. 308; Nunoura et al., 2009), the Peru continental margin, and the equatorial Pacific sediments (ODP Leg 201; Schippers et al., 2005; Inagaki et al., 2006; Schippers and Neretin, 2006), as well as gas-hydrate bearing sediments from the Cascadia margin (ODP Leg 204; Inagaki et al., 2006). The dominance of Bacteria for the Peru continental margin was confirmed by CARD-FISH (Schippers et al., 2005). Unlike nucleic acid based methods (CARD-FISH and Q-PCR), the analysis of intact polar lipids (IPL) of prokaryotic cell membranes unveiled Archaea as prevailing prokaryotes in deeply buried sediments (Biddle et al., 2006; Lipp et al., 2008). These conflicting results may be explained by insufficient quantitative extraction protocols, or primer mismatches (Teske and Sørensen, 2008) and/or a different preservation of DNA and IPL in deeply buried sediments (e.g., stabilized on clay surfaces or organic matter; Coolen et al., 2006a,b; Inagaki and Nealson, 2006; Schippers and Neretin, 2006; Boere et al., 2011). Recently, Schouten et al. (2010) as well as Logemann et al. (2011) reported the preservation of archaeal IPL biomarkers in marine sediments indicating that IPL biomarkers do not necessarily detect living Archaea and putting their proposed dominance in the deep biosphere into question. Obviously, it is not yet understood which factors control the proportions of Bacteria and Archaea in marine sediments.

Particular phylogenetic and physiological groups, inhabiting Black Sea and Benguela upwelling sediments, were revealed by Q-PCR in this study. The sediments were clearly dominated by prokaryotes since the abundance of eukaryotic $18 \mathrm{~S}$ rRNA genes 
Table 2 | Compilation of mean cell numbers $(\mathrm{N} / \mathrm{mL})$ in the depth range of 1-10 and 10-200 mbsf in subsurface marine sediments; nd, not determined.

\begin{tabular}{|c|c|c|c|c|c|c|c|}
\hline \multirow[t]{2}{*}{ Expedition } & $\begin{array}{l}\text { Total } \\
\text { counts }\end{array}$ & Q-PCR & $\begin{array}{l}\text { CARD- } \\
\text { FISH }\end{array}$ & $\begin{array}{l}\text { Total } \\
\text { counts }\end{array}$ & Q-PCR & $\begin{array}{l}\text { CARD- } \\
\text { FISH }\end{array}$ & \multirow[t]{2}{*}{ Reference } \\
\hline & \multicolumn{3}{|c|}{ 1-10 mbsf } & \multicolumn{3}{|c|}{$10-200 \mathrm{mbsf}$} & \\
\hline$\sim 20$ ODP and other sites & $10^{7}-10^{9}$ & nd & nd & $10^{6}-10^{8}$ & nd & nd & $\begin{array}{l}\text { Parkes et al. (1994, 2000), Bird et al. (2001), } \\
\text { Wellsbury et al. (2002), Inagaki etal. (2003), } \\
\text { Kallmeyer et al. (2008), Morono et al. } \\
\text { (2009), Roussel et al. (2009) }\end{array}$ \\
\hline ODP Leg 201 Equatorial Pacific & $10^{7}$ & nd & $10^{6}$ & $10^{6}-10^{7}$ & nd & $10^{6}$ & $\begin{array}{l}\text { D'Hondt et al. (2004), Schippers et al. } \\
\text { (2005) }\end{array}$ \\
\hline ODP Leg 201 Peru margin & $10^{7}-10^{8}$ & $10^{7}$ & $10^{6}$ & $10^{7}$ & $10^{6}$ & $10^{6}$ & $\begin{array}{l}\text { D'Hondt et al. (2004), Schippers et al. } \\
\text { (2005), Inagaki et al. (2006) }\end{array}$ \\
\hline ODP Leg 204 Cascadia margin & $10^{7}$ & $10^{7}$ & nd & $10^{6}$ & $10^{6}$ & nd & Inagaki et al. (2006), Nunoura et al. (2008) \\
\hline IODP 301 Juan de Fuca & $10^{8}-10^{9}$ & $10^{6}-10^{8}$ & nd & $10^{8}$ & $10^{6}$ & nd & Engelen et al. (2008) \\
\hline IODP 307 Porcupine Seamount & & & & $10^{6}-10^{7}$ & $10^{5}-10^{6}$ & $10^{5}-10^{6}$ & Webster et al. (2009) \\
\hline IODP 308 Gulf of Mexico & $10^{5}-10^{6}$ & $10^{5}-10^{6}$ & nd & $10^{4}-10^{5}$ & $10^{4}-10^{5}$ & nd & Nunoura et al. (2009) \\
\hline $\begin{array}{l}\text { IODP } 313 \text { New Jersey Shallow } \\
\text { Shelf }\end{array}$ & $10^{6}$ & $10^{5}-10^{6}$ & nd & $10^{5}-10^{6}$ & $10^{5}-10^{6}$ & nd & $\begin{array}{l}\text { A. Breuker, S. Stadler, and A. Schippers } \\
\text { (unpublished) }\end{array}$ \\
\hline North Sea tidal flat & $10^{7}-10^{8}$ & $10^{7}$ & nd & & & & Wilms et al. (2007) \\
\hline SO 189 Forearc off Sumatra & $10^{7}-10^{8}$ & $10^{7}-10^{8}$ & nd & & & & Schippers et al. (2010) \\
\hline South Pacific Gyre & $10^{3}-10^{4}$ & nd & nd & & & & D'Hondt et al. (2009) \\
\hline MSM 11-1 "North Pond" & $10^{5}-10^{6}$ & $10^{4}-10^{6}$ & nd & & & & A. Breuker and A. Schippers (unpublished) \\
\hline M 72-5 Black Sea & $10^{7}-10^{8}$ & $10^{5}-10^{6}$ & $10^{5}-10^{6}$ & & & & This study \\
\hline M 76-1 Benguela Upwelling & $10^{7}-10^{9}$ & $10^{6}-10^{8}$ & $10^{6}-10^{7}$ & & & & This study \\
\hline $\begin{array}{l}\text { ICDP Chesapeake Bay terrestrial } \\
\text { sediments }\end{array}$ & $10^{6}-10^{7}$ & $10^{6}-10^{7}$ & $10^{6}$ & $10^{6}$ & $10^{6}$ & nd & Breuker et al. (2011) \\
\hline
\end{tabular}

comprised only $3 \%$ and $<1 \%$ of the number of prokaryotic $16 \mathrm{~S}$ rRNA genes for the Black Sea and Namibia sediments, respectively. This can be attributed to the small pore space in subsurface sediments which impedes growth of large eukaryotic cells. Similar Q-PCR results were obtained for the organic carbon-rich sediments off Sumatra (Schippers et al., 2010) and for Peru margin sediments (Schippers and Neretin, 2006). In the latter sediments, mainly fungi have been identified as dominant Eukarya (Edgcomb et al., 2011). In the near-surface anoxic and sulfidic sediments of the Black Sea the following eukaryotic groups were detected via DGGE and 18S rRNA gene sequencing: copepods, rotifers, haptophytes, dinoflagellates, and ciliates (Coolen and Shtereva, 2009). Data on the composition of Eukarya in the deeper, subsurface sediment are not available.

As previously shown for the sediments off Sumatra, the Peru margin and the Black Sea station 20 (Blazejak and Schippers, 2010), the bacterial candidate division JS-1 and the classes Anaerolineae and Caldilineae of the phylum Chloroflexi were at least as highly abundant as the Bacteria for the other five stations of this study as well. This confirms their dominant role in subsurface marine sediments (Webster et al., 2004; Teske, 2006; Fry et al., 2008). Crenarchaeota were previously identified as dominant members in the archaeal 16S rRNA gene clone libraries (Teske, 2006; Fry et al., 2008; Teske and Sørensen, 2008). This is consistent with our finding that this group could be quantified by Q-PCR in comparable (or higher) copy numbers than the Archaea in subsurface marine sediments of the Black Sea and the Benguela upwelling sediments. Moreover, uncultured Crenarchaeota as well as Chloroflexi have also been identified in one subsurface sediment core (station GeoB 3703) from the Benguela upwelling area (Schäfer et al., 2007). In many samples of our study more Crenarchaeota than Archaea, and more JS-1 and Chloroflexi than Bacteria were detected. This discrepancy may be explained by PCR bias due to different PCR efficiencies for the particular Q-PCR assays, primer mismatches of the general 16S rRNA gene primers with predominant environmental gene sequences (Teske and Sørensen, 2008), and probably different 16S rRNA gene copy numbers per cell which are unknown for the particular specific archaeal and bacterial groups analyzed in this study.

Functional genes were quantified by Q-PCR to demonstrate the importance of particular physiological prokaryotic groups. The functional genes $d s r A$ and $a p r A$ of sulfate-reducers and the gene $m c r A$ of methanogens were highly abundant in the Black Sea as well as in the Namibia sediments. This finding is not surprising because sulfate reduction, methanogenesis, and anaerobic methane oxidation were shown to be important biogeochemical processes in these sediments (Niewöhner et al., 1998; Ferdelman et al., 1999; Fossing et al., 2000; Jørgensen et al., 2001, 2004; Brüchert et al., 2003, 2006; Knab et al., 2008; Riedinger et al., 2010; Holmkvist et al., 2011). Q-PCR based $d s r A$ quantification in another Black Sea subsurface sediment core also revealed that sulfate-reducers were highly abundant throughout the whole sampling depth of $4.6 \mathrm{mbsf}$ (Leloup et al., 2007). A $d s r A$ clone library 
in the same study showed mostly sequences affiliated with the Desulfobacteraceae.

The detection of the functional gene $c b b L$ coding for the large subunit of the form I "red-like" RuBisCO was different for the Black Sea and the Benguela upwelling samples. While in the latter the gene was detected in lower copy numbers in most samples and all depth, $c b b L$ was mainly detectable only in near-surface sediments of the Black Sea. Overall, autotrophy via the RuBisCO pathway seems to play some role in these samples, despite its high organic carbon content supporting heterotrophy as shown for the organic carbon-rich sediments of the Peru margin (D'Hondt et al., 2004; Biddle et al., 2006). A higher abundance of the same $c b b L$ gene than in this study was recently detected in the organic carbonpoor terrestrial subsurface sediments in the Chesapeake Bay area, VA, USA (Breuker et al., 2011). There, in agreement with the lower organic carbon content, autotrophy seems to be more important than in the marine sediments of this study.

\section{CONCLUSION}

The microbial communities in the subsurface marine sediments of the Black Sea and the Benguela upwelling area off Namibia have been quantitatively analyzed at six stations using total cell

\section{REFERENCES}

Badger, M. R., and Bek, E. J. (2008). Multiple Rubisco forms in proteobacteria: their functional significance in relation to $\mathrm{CO}_{2}$ acquisition by the CBB cycle. J. Exp. Bot. 59, 1525-1541.

Biddle, J. F., Fitz-Gibbon, S., Schuster, S. C., Brenchley, J. E., and House, C. H. (2008). Metagenomic signatures of the Peru Margin subseafloor biosphere show a genetically distinct environment. Proc. Natl. Acad. Sci. U.S.A. 105, 10583-10588.

Biddle, J. F., Lipp, J. S., Lever, M., Lloyd, K. G., Sørensen, K. B., Anderson, R., Fredricks, H. F., Elvert, M., Kelly, T. J., Schrag, D. P., Sogin, M. L., Brenchley, J. E., Teske, A., House, C. H., and Hinrichs, K. U. (2006). Heterotrophic archaea dominate sedimentary subsurface ecosystems off Peru. Proc. Natl. Acad. Sci. U.S.A. 103, 3846-3851.

Bird, D. F., Juniper, S. K., RicciardiRigault, M., Martineu, P., Prairie, Y. T., and Calvert, S. E. (2001). Subsurface viruses and bacteria in Holocene/Late Pleistocene sediments of Saanich Inlet, BC: ODP Holes 1033B and 1034B, Leg 169S. Mar. Geol. 174, 227-239.

Blazejak, A., and Schippers, A. (2010). High abundance of JS-1- and Chloroflexi-related bacteria in deeply buried marine sediments revealed by quantitative, real-time PCR. FEMS Microbiol. Ecol. 72, 198-207.

Blazejak, A., and Schippers, A. (2011). Real-time PCR quantification and diversity analysis of the functional genes aprA and $d s r A$ of sulfate-reducing bacteria in marine sediments of the Peru continental margin and the Black Sea. Front. Microbiol. 2:253. doi:10.3389/fmicb.2011.00253

Boere, A. C., Rijpstra, W. I. C., DeLange, G. J., Sinninghe Damsté, J. S., and Coolen, M. J. L. (2011). Preservation potential of ancient plankton DNA in Pleistocene marine sediments. Geobiology 9, 377-393.

Breuker, A., Köweker, G., Blazejak, A., and Schippers, A. (2011). The deep biosphere in terrestrial sediments of the Chesapeake Bay impact structure, Virginia, USA. Front. Microbiol. 2:156. doi:10.3389/fmicb.2011.00156

Brüchert, V., Currie, B., Peard, K. R., Lass, U., Endler, R., Dübecke, A., Julies, E., Leipe, T., and Zitzmann, S. (2006). "Biogeochemical and physical control on shelf anoxia and water column hydrogen sulphide in the Benguela coastal upwelling system off Namibia," in Past and Present Water Column Anoxia, NATO Science Series, IV. Earth and Environmental Sciences, Vol. 64, ed. L. N. Neretin (Heidelberg: Springer), 161-193.

Brüchert, V., Jørgensen, B., Neumann, K., Riechmann, D., Schlösser, M., and Schulz, H. N. (2003). Regulation of bacterial sulfate reduction and hydrogen sulfide fluxes in the central Namibian coastal upwelling zone. Geochim. Cosmochim. Acta 67, 4505-4518.

counts, CARD-FISH and 12 different Q-PCR assays. A high abundance of Prokaryotes and overall similar proportions of Bacteria and Archaea were discovered in the eutrophic, organic carbonrich sediments. Crenarchaeota and the bacterial candidate division JS-1 and the classes Anaerolineae and Caldilineae of the phylum Chloroflexi were as highly abundant. In agreement with the reported ongoing sulfate reduction and methanogenesis, the functional genes $d s r A$ and $a p r A$ of sulfate-reducers and the gene $m c r A$ of methanogens were highly abundant as well, suggesting a vital microbial community performing these processes. The detection of the $c b b L$ gene shows the occurrence of autotrophic microorganisms.

\section{ACKNOWLEDGMENTS}

We thank the RV Meteor M72-5 and M76-1 chiefs C. Borowski, T. G. Ferdelman and M. Zabel, and especially B. Engelen for helpful suggestions and advice. Special thanks also go to G. Mengel-Jung and C. Struckmeyer for laboratory analyses, and S. Eckert, B. Schnettger, Y. Lin, and K.-U. Hinrichs for providing TOC data. This work was supported by the German Research Foundation (DFG) priority program IODP/ODP grant SCHI 535/7 to Axel Schippers.

Brüchert, V., Perez, M. E., and Lange C. B. (2000). Coupled primary production, benthic foraminiferal assemblage, and sulfur diagenesis in organic-rich sediments of the Benguela upwelling system. Mar. Geol. 163, 27-40.

Brumsack, H.-J. (1989). Geochemistry of recent TOC-rich sediments from the Gulf of California and the Black Sea. Geol. Rundsch. 78, 851-882.

Colwell, F. S., Boyd, S., Delwiche, M. E., Reed, D. W., Phelps, T. J., and Newby, D. T. (2008). Estimates of biogenic methane production rates in deep marine sediments at Hydrate Ridge, Cascadia Margin. Appl. Environ. Microbiol. 74, 3444-3452.

Coolen, M. J. L., Boere, A., Abbas, B., Baas, M., Wakeham, S. G., and Sinninghe Damsté, J. S. (2006a). Fossil DNA derived from alkenonebiosynthesizing haptophytes and other algae in Holocene sediment from the Black Sea. Paleoceanography 21, 1-17.

Coolen, M. J. L, Muyzer, G., Schouten, S., Volkman, J. K., and Sinninghe Damsté, J. S. (2006b). "Sulfur and methane cycling during the Holocene in Ace Lake (Antarctica) revealed by lipid and DNA stratigraphy," in Past and Present Water Column Anoxia, NATO Science Series, IV. Earth and Environmental Sciences, Vol. 64, ed. L. N. Neretin (Heidelberg: Springer), 41-65.

Coolen, M. J. L., Cypionka, H., Sass, A. M., Sass, H., and
Overmann, J. (2002). Ongoing modification of Mediterranean Pleistocene sapropels mediated by prokaryotes. Science 296, 2407-2410.

Coolen, M. J. L., and Shtereva, G. (2009) Vertical distribution of metabolically active eukaryotes in the water column and sediments of the Black Sea. FEMS Microbiol. Ecol. 70, 525-539.

Dale, A. W., Brüchert, V., Alperin, M., and Regnier, P. (2009). An integrated sulfur isotope model for Namibian shelf sediments. Geochim. Cosmochim. Acta 73, 1924-1944.

D'Hondt, S., Spivack, A. J., Pockalny, R., Ferdelman, T. G., Fischer, J. P., Kallmeyer, J., Abrams, L. J., Smith, D. C., Graham, D., Hasiuk, F., Schrum, H., and Stancin, A. M. (2009). Subseafloor sedimentary life in the South Pacific Gyre. Proc. Natl. Acad. Sci. U.S.A. 106, 11651-11656.

D’Hondt, S. L., Jørgensen, B. B., Miller, D. J., Batzke, A., Blake, R., Cragg, B. A., Cypionka, H., Dickens, G. R., Ferdelman, T. G., Hinrichs, K. U., Holm, N. G., Mitterer, R., Spivack, A., Wang, G., Bekins, B., Engelen, B. Ford, K., Gettemy, G., Rutherford, S. D., Sass, H., Skilbeck, C. G., Aiello, I. W., Guèrin, G., House, C. H., Inagaki, F., Meister, P., Naehr, T., Niitsuma, S., Parkes, R. J., Schippers, A., Smith, D. C., Teske, A., Wiegel, J., Padilla, C. N., and Solis Acosta, J. L. (2004). Distributions of microbial activities in deep subseafloor sediments. Science 306, 2216-2221. 
Edgcomb, V. P., Beaudoin, D., Gast, R., Biddle, J. F., and Teske, A. (2011). Marine subsurface eukaryotes: the fungal majority. Environ. Microbiol. 13, 172-183.

Emeis, K., Brüchert, V., Currie, B., Endler, R., Ferdelman, T., Kiessling, A., Leipe, T., Noli-Peard, K., Struck, U., and Vogt, T. (2004). Shallow gas in shelf sediments of the Namibian coastal upwelling ecosystem. Cont. Shelf Res. 24, 627-642.

Engelen, B., Ziegelmüller, K., Wolf, L., Köpke, B., Gittel, A., Cypionka, H., Treude, T., Nakagawa, S., Inagaki, F., Lever, M. A., and Steinsbu, B. O. (2008). Fluids from the oceanic crust support microbial activities within the deep biosphere. Geomicrobiol. J. 25, 55-66.

Ferdelman, T. G., Fossing, H., Neumann, K., and Schulz, H. D. (1999). Sulfate reduction in surface sediments of the southeast Atlantic continental margin between $15^{\circ} 38^{\prime} \mathrm{S}$ and $27^{\circ} 57^{\prime} \mathrm{S}$ (Angola and Namibia). Limnol. Oceanogr. 44, 650-661.

Fossing, H., Ferdelman, T. G., and Berg, P. (2000). Sulfate reduction and methane oxidation in continental margin sediments influenced by irrigation (South-East Atlantic off Namibia). Geochim. Cosmochim. Acta 64, 897-910.

Fry, J. C., Parkes, R. J., Cragg, B. A., Weightman, A. J., and Webster, G. (2008). Prokaryotic diversity and activity in the deep subseafloor biosphere. FEMS Microbiol. Ecol. 66, 181-196.

Goldhammer, T., Brüchert, V., Ferdelman, T. G., and Zabel, M. (2010). Microbial sequestration of phosphorus in anoxic upwelling sediments. Nat. Geosci. 3, 557-561.

Goldhammer, T., Brunner, B., Bernasconi, S. M., Ferdelman, T. G., and Zabel, M. (2011). Phosphate oxygen isotopes: insights into sedimentary phosphorus cycling from the Benguela upwelling system. Geochim. Cosmochim. Acta 75, 3741-3756.

Holmes, D. E., Finneran, K. T., O'Neil, R. A., and Lovley, D. R. (2002). Enrichment of members of the family Geobacteraceae associated with stimulation of dissimilatory metal reduction in uranium-contaminated aquifer sediments. Appl. Environ. Microbiol. 68, 2300-2306.

Holmkvist, L., Kamyshny, A. Jr., Vogt, C., Vamvakopoulos, K., Ferdelman, T. G., and Jørgensen, B. B. (2011). Sulfate reduction below the sulfate-methane transition in
Black Sea sediments. Deep Sea Res. Part I Oceanogr. Res. Pap. 58, 493-504.

Inagaki, F., and Nealson, K. H. (2006). "The paleome: letters from ancient earth", in Past and Present Water Column Anoxia, NATO Science Series, IV. Earth and Environmental Sciences, Vol. 64, ed. L. N. Neretin (Heidelberg: Springer), 21-39.

Inagaki, F., Nunoura, T., Nakagawa, S., Teske, A., Lever, M., Lauer, A., Suzuki, M., Takai, K., Delwiche, M., Colwell, F. S., Nealson, K. H., Horikoshi, K., D’Hondt, S., and Jørgensen, B. B. (2006). Biogeographical distribution and diversity of microbes in methane hydrate-bearing deep marine sediments on the Pacific ocean margin. Proc. Natl. Acad. Sci. U.S.A. 103, 2815-2820.

Inagaki, F., Suzuki, M., Takai, K., Oida, H., Sakamoto, T., Aoki, K., Nealson, K. H., and Horikoshi, K. (2003). Microbial communities associated with geological horizons in coastal subseafloor sediments from the Sea of Okhotsk. Appl. Environ. Microbiol. 69, 7224-7235.

Jørgensen, B. B., Böttcher, M. E., Holger, L., Neretin, L. N., and Volkov, I. I. (2004). Anaerobic methane oxidation and a deep $\mathrm{H}_{2} \mathrm{~S}$ sink generate isotopically heavy sulfides in Black Sea sediments. Geochim. Cosmochim. Acta 68, 2095-2118.

Jørgensen, B. B., Weber, A., and Zopfi, J. (2001). Sulfate reduction and anaerobic methane oxidation in Black Sea sediments. Deep Sea Res. Part I Oceanogr. Res. Pap. 48, 2097-2120.

Julies, E. M., Fuchs, B. M., Arnosti, C., and Brüchert, V. (2010). Organic carbon degradation in anoxic organic-rich shelf sediments: biogeochemical rates and microbial abundance. Geomicrobiol. J. 27, 303-314.

Kallmeyer, J., Smith, D. C., Spivack, A. J., and D'Hondt, S. L. (2008). New cell extraction procedure applied to deep subsurface sediments. Limnol. Oceanogr. Methods 6, 236-245.

Knab, N. J., Cragg, B. A., Hornibrook, E. R. C., Holmkvist, L., Borowski, C., Parkes, R. J., and Jørgensen, B. B. (2008). Regulation of anaerobic methane oxidation in sediments of the Black Sea. Biogeosci. Discuss. 5, 2305-2341.

Knoblauch, C., Jørgensen, B. B., and Harder, J. (1999). Community size and metabolic rates of psychrophilic sulfate-reducing bacteria in Arctic marine sediments. Appl. Environ. Microbiol. 65, 4230-4233.
Leloup, J., Loy, A., Knab, N. J., Borowski, C., Wagner, M., and Jørgensen, B. B. (2007). Diversity and abundance of sulfate-reducing microorganisms in the sulfate and methane zones of a marine sediment, Black Sea. Environ. Microbiol. 9, 131-142.

Lipp, J. S., Morono, Y., Inagaki, F., and Hinrichs, K. U. (2008). Significant contribution of Archaea to extent biomass in marine subsurface sediments. Nature 454, 991-994.

Logemann, J., Graue, J., Köster, J., Engelen, B., Rullkötter, J., and Cypionka, H. (2011). A laboratory experiment of intact polar lipid degradation in sandy sediments. Biogeosci. Discuss. 8, 3289-3321.

Morono, Y., Terada, T., Masui, N., and Inagaki, F. (2009). Discriminative detection and enumeration of microbial life in marine subsurface sediments. ISME J. 3, 503-511.

Nadkarni, M., Martin, F. E., Jacques, N. A., and Hunter, N. (2002). Determination of bacterial load by real-time PCR using a broad range (universal) probe and primer set. Microbiology 148, 257-266

Neretin, L. N., Abed, R. M. M., Schippers, A., Schubert, C. J., Kohls, K., and Kuypers, M. M. M. (2007). Inorganic carbon fixation by sulfatereducing bacteria in the Black Sea water column. Environ. Microbiol. 9, 3019-3024.

Neretin, L. N., Böttcher, M. E., Jørgensen, B. B., Volkov, I. I., Lüschen, H., and Hilgenfeldt, K. (2004). Pyritization processes and greigite formation in the advancing sulfidization front in the upper Pleistocene sediments of the Black Sea. Geochim. Cosmochim. Acta 68, 2081-2093.

Niewöhner, C., Hensen, C., Kasten, S., Zabel, M., and Schulz, H. D. (1998). Sulfate reduction completely mediated by anaerobic methane oxidation in sediments of the upwelling area off Namibia. Geochim. Cosmochim. Acta 62, 455-464.

Nunoura, T., Inagaki, F., Delwiche, M. E., Colwell, F. S., and Takai, K. (2008). Subseafloor microbial communities in methane hydratebearing sediments of two distinct locations (ODP Leg 204) in the Cascadia margin. Microbes Environ. 23, 317-325.

Nunoura, T., Soffientino, B., Blazejak, A., Kakuta, J., Oida, H., Schippers, A., and Takai, K. (2009). Subseafloor microbial communities associated with rapid turbidite deposition in the Gulf of Mexico continental slope (IODP Expedition
308). FEMS Microbiol. Ecol. 69, 410-424.

Ochsenreiter, T., Selezi, D., Quaiser, A., Bonch-Osmolovskaya, L., and Schleper, C. (2003). Diversity and abundance of Crenarchaeota in terrestrial habitats studied by $16 \mathrm{~S}$ RNA surveys and real time PCR. Environ. Microbiol. 5, 787-797.

Parkes, R. J., Cragg, B. A., Bale, S. J., Getliff, J. M., Goodman, K., Rochelle, P. A., Fry, J. C., Weightman, A. J., and Harvey, S. M. (1994). Deep bacterial biosphere in Pacific Ocean sediments. Nature 371, 410-413.

Parkes, R. J., Cragg, B. A., and Wellsbury, P. (2000). Recent studies on bacterial populations and processes in subseafloor sediments: a review. Hydrogeol. J. 8, 11-28.

Parkes, R. J., Webster, G., Cragg, B. A., Weightman, A. J., Newberry, C. J., Ferdelman, T. G., Kallmeyer, J., Jørgensen, B. B., Aiello, I. W., and Fry, J. C. (2005). Deep sub-seafloor prokaryotes stimulated at interfaces over geological time. Nature 436, 390-394.

Pernthaler, A., Pernthaler, J., and Amann, R. (2002). Fluorescence in situ hybridization and catalyzed reporter deposition for the identification of marine bacteria. Appl. Environ. Microbiol. 68, 3094-3101.

Ravenschlag, K., Sahm, K., Knoblauch, C., Jørgensen, B. B., and Amann, R. (2000). Community structure, cellular rRNA content and activity of sulfate-reducing bacteria in marine Arctic sediments. Appl. Environ. Microbiol. 66, 3592-3602.

Riedinger, N., Brunner, B., Lin, Y.-S., Voßmeyer, A., Ferdelman, T. G., and Jørgensen, B. B. (2010). Methane at the sediment-water transition in the Black Sea sediments. Chem. Geol. 274, 29-37.

Roussel, E. G., Sauvadet, A.-L., Chaduteau, C., Fouquet, Y., Charlou, J.-L., Prieur, D., and Cambon Bonavita, M.-A. (2009). Archaeal communities associated with shallow to deep subseafloor sediments of the New Caledonia Basin. Environ. Microbiol. 11. 2446-2462.

Sahm, K., Knoblauch, C., and Amann, R. (1999). Phylogenetic affiliation and quantification of psychrophilic sulfate-reducing isolates in marine Arctic sediments. Appl. Environ. Microbiol. 65, 3976-3981.

Schäfer, H., Ferdelman, T. G., Fossing, H., and Muyzer, G. (2007). Microbial diversity in deep sediments of the Benguela Upwelling System. Aquat. Microb. Ecol. 50, 1-9.

Schippers, A., Köweker, G., Höft, C., and Teichert, B. (2010). Quantification 
of microbial communities in three forearc sediment basins off Sumatra. Geomicrobiol. J. 27, 170-182.

Schippers, A., and Neretin, L. N. (2006). Quantification of microbial communities in near-surface and deeply buried marine sediments on the Peru continental margin using realtime PCR. Environ. Microbiol. 8, 1251-1260.

Schippers, A., Neretin, L. N., Kallmeyer, J., Ferdelman, T. G., Cragg, B. A., Parkes, R. J., and Jørgensen, B. B. (2005). Prokaryotic cells of the deep sub-seafloor biosphere identified as living bacteria. Nature 433, 861-864.

Schouten, S., Middelburg, J. J., Hopmans, E. C., and Sinninghe Damsté, J. S. (2010). Fossilization and degradation of intact polar lipids in deep subsurface sediments: a theoretical approach. Geochim. Cosmochim. Acta 74, 3806-3814.

Schubotz, F., Wakeham, S. G., Lipp, J. S., Fredricks, H. F., and Hinrichs, K.-U. (2009). Detection of microbial biomass by intact membrane lipid analysis in the water column and surface sediments of the Black Sea. Environ. Microbiol. 11, 2720-2734.

Schulz, H. N., Brinkhoff, T., Ferdelman, T. G., Mariné, M. H., Teske, A., and Jørgensen, B. B. (1999). Dense populations of a giant sulfur bacterium in Namibian shelf sediments. Science 284, 493-495.
Schulz, H. N., and Schulz, H. D. (2005). Large sulfur bacteria and the formation of phosphorite. Science 307, 416-418.

Selesi, D., Pattis, I., Schmid, M., Kandeler, E., and Hartmann, A. (2007). Quantification of bacterial RubisCO genes in soils by cbbL targeted realtime PCR. J. Microbiol. Methods 69, 497-503.

Steinberg, L. M., and Regan, J. M. (2009). $m c r A$-targeted real-time quantitative PCR method to examine methanogen communities. Appl. Environ. Microbiol. 75, 4435-4442.

Takai, K., and Horikoshi, K. (2000). Rapid detection and quantification of members of the archaeal community by quantitative PCR using fluorogenic probes. Appl. Environ. Microbiol. 66, 5066-5072.

Teske, A. P. (2006). Microbial communities of deep marine subsurface sediments: molecular and cultivation surveys. Geomicrobiol. J. 23, 357-368.

Teske, A. P., and Sørensen, K. B. (2008). Uncultured archaea in deep marine subsurface sediments: have we caught them all? ISME J. 2, 3-18.

Thamdrup, B., Rosselló-Mora, R., and Amann, R. (2000). Microbial manganese and sulfate reduction in Black Sea shelf sediments. Appl. Environ. Microbiol. 66, 2888-2897.

Webster, G., Blazejak, A., Cragg, B. A., Schippers, A., Sass, H., Rinna, J., Tang, X., Mathes, F., Ferdelman, T. G., Fry, J. C., Weightman, A. J., and Parkes, R. J. (2009). Subsurface microbiology and biogeochemistry of a deep, cold-water carbonate mound from the Porcupine Seabight (IODP Expedition 307). Environ. Microbiol. 11, 239-257.

Webster, G., Newberry, C. J., Fry, J. C., and Weightman, A. J. (2003). Assessment of bacterial community structure in the deep sub-seafloor biosphere by $16 \mathrm{~S}$ rDNA-based techniques: a cautionary tale. J. Microbiol. Methods 55, 155-164.

Webster, G., Parkes, R. J., Fry, J. C., and Weightman, A. J. (2004). Widespread occurrence of a novel division of bacteria identified by $16 \mathrm{~S}$ rDNA gene sequences originally found in deep marine sediments. Appl. Environ. Microbiol. 70, 5708-5713.

Weinbauer, M. G., Beckmann, C., and Höfle, M. G. (1998). Utility of green fluorescent nucleic acid dyes and aluminium oxide membrane filters for rapid epifluorescence enumeration of soil and sediment bacteria. Appl. Environ. Microbiol. 64, 5000-5003.

Wellsbury, P., Mather, I., and Parkes, R. J. (2002). Geomicrobiology of deep, low organic-carbon sediments in the Woodlark Basin, Pacific Ocean. FEMS Microbiol. Ecol. 42, 59-70.

Wilms, R., Sass, H., Köpke, B., Cypionka, H., and Engelen, B. (2007). Methane and sulfate profiles within the subsurface of a tidal flat are reflected by the distribution of sulfatereducing bacteria and methanogenic archaea. FEMS Microbiol. Ecol. 59, 611-621.

Yilmaz, A., Çoban-Yildiz, Y., Telli-Karakoç, F., and Bologa, A. (2006). Surface and mid-water sources of organic carbon by photoautotrophic and chemoautotrophic production in the Black Sea. Deep Sea Res. Part II Top. Stud. Oceanogr. 53, 1988-2004.

Conflict of Interest Statement: The authors declare that the research was conducted in the absence of any commercial or financial relationships that could be construed as a potential conflict of interest.

Received: 07 September 2011; paper pending published: 06 October 2011 accepted: 09 January 2012; published online: 30 January 2012.

Citation: Schippers A, Kock D, Höft C, Köweker G and Siegert M (2012) Quantification of microbial communities in subsurface marine sediments of the Black Sea and off Namibia. Front. Microbio. 3:16. doi: 10.3389/fmicb.2012.00016

This article was submitted to Frontiers in Extreme Microbiology, a specialty of Frontiers in Microbiology.

Copyright () 2012 Schippers, Kock, Höft, Köweker and Siegert. This is an openaccess article distributed under the terms of the Creative Commons Attribution Non Commercial License, which permits non-commercial use, distribution, and reproduction in other forums, provided the original authors and source are credited. 